\title{
Additional Surgery for New Loco-Regional Tumor Event Was Performed
}

National Cancer Institute

\section{Source}

National Cancer Institute. Additional Surgery for New Loco-Regional Tumor Event Was

Performed. NCI Thesaurus. Code C160444.

Additional surgery was performed for a new loco-regional tumor event. 